\title{
Minimizing maternal effect in salmonid families mixed since eyed stages and a posteriori DNA-pedigreed
}

\author{
P. Haffray ${ }^{a, *}$, M. Vandeputte ${ }^{b, d}$, V. Petit ${ }^{c}$, C. Pincent ${ }^{a}$, B. Chatain ${ }^{d}$, H. Chapuis ${ }^{e}$, J.C. Mériaux ${ }^{f}$,
} B. Coudurier ${ }^{g}$, E. Quillet ${ }^{b}$, M. Dupont-Nivet ${ }^{b}$

\author{
a SYSAAF, Station SCRIBE, Campus de Beaulieu, F-35042 Rennes, France \\ b INRA, UMR 1313 GABI Génétique Animale et Biologie Intégrative, F-78350 Jouy-en-Josas, France \\ ${ }^{c}$ Aqualande, F-40120 Pissos, France \\ d IFREMER, F-34250 Palavas les Flots, France \\ e SYSAAF, Unité SRA/INRA, F-37380 Nouzilly, France \\ ${ }^{f}$ LABOGENA, Domaine de Vilvert, F-78350 Jouy-en-Josas, France \\ ${ }^{g}$ INRA, CODIR Agriculture, 147 rue de l'Université, F-75338 Paris, France \\ *: Corresponding author: P. Haffray, tel.: +33223485378 ; fax: +33223485660 ; \\ email address : haffray@rennes.inra.fr
}

\begin{abstract}
:
Application of DNA parentage assignment for commercial selection in aquaculture is still rare. An experiment was performed to quantify and to minimize maternal effects on growth in rainbow trout. Six hundred families were reared until 198 day post fertilization (dpf) according to two different procedures. In the first procedure (NORM), all families were pooled at eyed stage. In the second procedure (MIN), where maternal effects due to differences in egg size were expected to be minimal, the spawns were divided into sub-groups with similar mean egg weight at eyed stage. These subgroups were then pooled when they achieved the same mean body length (147 dpf). Genetic parameters were estimated for body weight, body length and condition factor at $198 \mathrm{dpf}$, with 2964 fish assigned to their parents using microsatellites. Significant maternal effects were observed in the NORM group for body weight and body length $\left(m^{2}=0.08 \pm 0.03\right)$. The heritability of body weight was $0.16 \pm 0.07$ in the NORM group and $0.36 \pm 0.06$ in the MIN group, in which maternal effects were not significant. It is concluded that, when eggs of different females are mixed at eyed stage, maternal effects persist at least until $198 \mathrm{dpf}$. The proposed procedure efficiently limits maternal effects, substantially increasing the heritability for growth, and therefore the expected selection response.
\end{abstract}

Keywords : Rainbow trout ; Fingerprint ; Maternal effect ; Heritability ; Growth ; Triploid 


\section{INTRODUCTION}

Classic selection schemes in aquaculture require each family to be reared separately for several months. A minimum size must be attained to enable physical tagging to identify the pedigree of individuals so that families can be reared together in a common environment. DNA parentage assignment offers new possibilities for the optimization of selection schemes (Herbinger et al., 1995; Estoup et al., 1998). This technology should limit investment in multiple tanks for the rearing of each family and should decrease labour costs associated with their maintenance. It should also avoid common environment bias associated with uncontrolled "tank" effect, since all candidates would be reared in the same tank i.e., in the same environment (Herbinger et al., 1999). Publications on uses of this technology in salmonids are rare and generally report low to intermediate heritabilities for traits like growth, processing yields, flesh colour, filet lipid content and survival after diseases (Fishback et al., 2002; Norris and Cunningham, 2004; Guy et al., 2006; Norris et al., 2008; Pierce et al., 2008; Dupont-Nivet et al., 2010).

When designing a breeding program, variation due to maternal effects can interfere with the phenotype under selection and introduce bias (Falconer and MacKay, 1996). In fishes, maternal effects cover numerous biological aspects (see reviews by Berg et al., 2001; Green, 2008; Bobe and Labbé, 2010) such as: (1) difference in egg quality between dams (femalemediated provisioning of yolk reserve or nutrients and other compounds such as hormones too costly to measure for breeding purpose on a high number of candidates); (2) incomplete egg maturity; (3) egg over-maturation; (4) difference in egg size, which can relate to maternal size (and age) and offspring size; and (5) difference in hatching time, which can artificially create early differences in growth. In fish with small eggs, limited lipid reserve and very short embryonic stage, maternal effect are very limited and non significant (Dupont-Nivet et al., 
2008; Ninh et al., 2011). The general picture in salmonids, which have a large egg size (4-7 $\mathrm{mm}$ ) and cannot be tagged individually at hatching, is that maternal effects are observed up to 40-60 g body weight when families are mixed after several months of separate rearing (Aulstad, 1972; Gall, 1974; Chevassus, 1976; Refstie, 1980; Mc Kay, 1986a; Silverstein et al., 1994; Martínez et al., 1999). At the fry stage, it was estimated that egg size accounts for more than $70 \%$ of the variance in growth (Vandeputte et al., 2002). Maternal effects decrease in the early months after hatching (Chevassus, 1976) but can persist up to two years in rainbow trout (Mc Kay et al., 1986b; Crandell and Gall, 1993) and 18 months in Arctic char (Nilsson, 1994). All these estimates were obtained with families that were reared separately. However, this rearing system does not allow the maternal effects to be separated from the initial tank effects.

The maternal effects shown previously may bias the estimation of genetic parameters in cases when all candidates are mixed at an early biological stage (i.e., eyed stage in salmonids). Blanc (2002), using golden mutant of rainbow trout, estimated that within-group effects of difference in egg size were greater than between-group variation and persisted over at least 3month-old, a $1 \%$ difference in eyed egg weight resulted in a $0.5 \%$ difference in fry weight. In first experiments with trout families mixed at hatching, maternal effect was not considered (Fishback et al., 2002) or was impossible to estimate as dams with similar egg sizes were used (Dupont-Nivet et al., 2010). In a preliminary experiment with 2 dams with similar or different egg sizes, the heritability estimation for growth was lower when the difference of egg sizes was high (Chevassus et al., 2002). The management of these differences in egg weight has been proposed as a possible way of minimizing maternal effects to improve the efficiency of individual selection for growth in salmonids (Chevassus et al., 2004). However, although the overall efficiency of the selection proposed has been demonstrated, the true usefulness of managing differences in egg weight still needs to be investigated. 
The present study was designed to evaluate additive and maternal effects on growth in rainbow trout families reared together from eyed stage before hatching. In parallel, as it was predicted that initial differences in egg weight could result in lower heritability estimates (Chevassus et al., 2002), an alternative procedure, aiming at minimizing maternal effects, was investigated with the same families. As proposed in Chevassus et al. (2004), this second procedure managed the difference in egg weight through the formation of groups of families from dams with similar egg weight. Expected results included the quantification of maternal effect for growth at the juvenile stage in rainbow trout to increase selection efficiency.

\section{MATERIAL AND METHODS}

\subsection{Fish management}

The experiment was conducted in the Aqualande breeding centre at Pissos, located on the Leyre river in the Landes (southwest France, $44^{\circ} 18^{\prime} 27.61^{\prime \prime} \mathrm{N}, 0^{\circ} 46^{\prime} 43.00 \mathrm{O}$ ). The water temperature at this site varies from $3{ }^{\circ} \mathrm{C}$ in winter to $20{ }^{\circ} \mathrm{C}$ in summer. Fish were raised in fiberglass tanks until they reached $0.5 \mathrm{~g}$ and then in concrete raceways until the end of the experiment. Dissolved oxygen was maintained above $80 \%$ of saturation with liquid oxygen.

\subsection{Composition of the experimental groups}

The fish used were derived from a commercial line from the Aqualande breeding company (France). This line was already selected for growth over 3 generations using improved PROSPER principles (Chevassus et al., 2004) and integrating selection on external morphology and pedigree tracing using DNA parentage assignment since three generations 
(Haffray et al., 2004). The inbreeding (F) level of the population estimated with the "pedigree" package of the R software was $0.45 \%$.

To produce all families the same day, and thus avoiding maternal bias associated with fertilization date, ovulations were induced using one intra-peritoneal injection of Gonazon (GnRH analogue; Intervet: $32 \mu \mathrm{g} / / \mathrm{kg}$ body weight) according to the manufacturer recommendation and Haffray et al., (2008). Female body weight (FBW, $\pm 50 \mathrm{~g}$ ) at egg collection and total egg collected per female $( \pm 0.1 \mathrm{~g})$ were weighed for subsequent examination of maternal traits. All parents were fin clipped for later genotyping.

Six hundred all-female families were produced by mating 60 females ( 2 years old) and 100 neo-males (masculinized females) in ten full factorial designs (Figure 1) in each of which 6 dams were crossed with 10 sires according to Dupont-Nivet et al., (2006). For each dam, ten equal aliquots of eggs were fertilized by the sperm of ten different sires. The ten maternal half-sib families were pooled after fertilization and incubated together. Egg number and survival rate at eyed stage were estimated by dam using a SUSTAF $10^{6}$ automatic grader (IMV-Technologies, France). Mean egg weight was measured on 500 eyed eggs per dam.

At eyed stage, two groups were created with different expected intensity of maternal effect:

- the NORM group ("normal" group with expected highest maternal effect): 150 randomly-sampled eggs from each of the 60 dams were pooled;

- the MIN group ("minimum” group, with expected lowest maternal effect): 12 subgroups of 5 spawns were created by pooling 2500 eggs per spawn with equivalent mean egg weight per spawn.

Fish were fed 6 times a day using extruded commercial feeds with 19 MJ digestible energy (Le Gouessant, Lamballe, France): Neo Supra Al (58\% proteins, $13 \%$ lipids) from $1^{\text {st }}$ feeding to $6 \mathrm{gr}$, Neo Start 2 (52\% proteins, 17\% lipids) de 6 gr à 15 gr, Neo Start 3 (47\% proteins, $18 \%$ lipids) de 15 gr à 40 gr and Neo Extra (43\% proteins, 23\% lipids) from $40 \mathrm{~g}$ to the end of 
the experiment. Fish from the NORM group and sub-groups from the MIN group with smaller mean egg weight were fed at apparent satiation. Sub-groups with higher mean egg weight were slightly underfed (maximum $90 \%$ of apparent satiation of the other groups) to minimize their growth. At $147 \mathrm{dpf}$, when the 12 sub-groups of the MIN group reached similar fork length $(9.7 \mathrm{~cm} ; \mathrm{n}=100$ fish measured in each sub-group; ANOVA; $p<0.05), 250$ juveniles from each sub-group were randomly sampled and pooled.

2.3 Growth data recording, DNA sampling and genotyping

At 198 dpf, 1000 fish (NORM group) and 2020 fish (MIN group) were sampled at random, individually weighed (BW) and measured for body length (BL). The number of fish was different between these groups because the MIN group was also used for other experiments. Fin samples were stored in $95 \%$ ethanol for later DNA extraction. Fish were assigned to their parents by Labogena (Jouy en Josas, France) using twelve microsatellites organised in 2 panels. Only fish unambiguously assigned to both their parents by exclusion method and with a maximum of one allowed mismatches were included in the statistical analysis.

\subsection{Data analysis}

Fulton condition coefficient $\mathrm{K}\left(\mathrm{BW} / \mathrm{BL}^{3}\right)$ and relative fecundity (egg number / $\mathrm{BW}$ ) were calculated. The mean and standard deviation of each trait were calculated using SAS version 9.1.

Heritability was estimated using VCE 6 software (Kovac and Groeneveld, 2003) with an univariate animal model for each trait:

$Y=X \beta+Z a+W m+\varepsilon$ 
where $\underline{Y}$ is the vector of observations, $\underline{\beta}$ the vector of fixed effects (sub-groups effect for MIN group), $\underline{a}$ the vector of random additive genetic effects, $\underline{m}$ the vector of maternal effect relates to effects linked to the dam other than the additive genetic effect of the dam (i.e. permanent environment effects and additive effects in maternal aptitudes), and $\underline{\varepsilon}$ the random vector of residual effects. $\underline{X}, \underline{Z}$ and $\underline{\mathrm{W}}$ are known incidence matrices.

Genetic correlations between the same trait in the NORM and MIN groups were estimated with a bivariate animal model considering trait in each group as two different traits. The environmental co-variance was set to zero.

The significance of the maternal effect was evaluated by comparing the log-likelihoods (2LL) of models with or without maternal effect. A difference between models was considered as significant when it was higher than the threshold value of the Chi-square test with one degree of freedom and $\mathrm{P}=0.05\left(\chi^{2}=3.84\right)$.

Finally, the origin of the maternal effect was examined by linear regression between family means of body weight and maternal traits (mean egg weight, dam weight, egg number, relative fecundity and survival rate at eyed stage) and by testing addition of covariates incorporated into the univariate animal model in the NORM group.

\section{RESULTS}

\subsection{Reproductive and growing performances}

Spawning induction success after 10 days after injection was $95.6 \%$. Mean body weight (BW \pm SD) at spawning was $5417 \pm 549 \mathrm{~g}$. Mean egg weight was $76.7 \pm 7.0 \mathrm{mg}$ and mean survival at eyed stage $81.3 \pm 10.9 \%$. 
The mean body weight at $198 \mathrm{dpf}$ was $69.1 \pm 17.6 \mathrm{~g}$ in the NORM group $(\mathrm{n}=1000)$ and 73.1 $\pm 17.6 \mathrm{~g}$ in the MIN group $(\mathrm{n}=1925)$. BL was $17.6 \pm 1.4 \mathrm{~cm}$ and $17.8 \pm 1.4 \mathrm{~cm}$ for NORM and MIN, respectively, and $\mathrm{K}$ was $1.24 \pm 0.08$ and $1.25 \pm 0.10$.

\subsection{Parentage assignment and parental and family representations}

In the NORM group, $100 \%$ of the individuals $(\mathrm{n}=1000)$ were assigned to unique pairs, with $79.3 \%$ of the expected 600 full-sib families $(n=476)$ represented in the genotyped progeny. The number of progeny per family represented ranged from 1 to 6 . From the 100 sires used, 99 were represented in the progeny. The mean number of progeny per sire was $10.1 \pm 4.0$. The progeny number per sire ranged from 3 to 26. Although two of the sires had 21 and 26 progeny, these 2 sires represented only $4.7 \%$ of the progeny. All 60 dams were represented in the genotyped progeny. The mean number of progeny per dam was $16.6 \pm 5.2$, and ranged from 6 to 28 .

In the MIN group, 2020 fish were genotyped, out of which 2015 were assigned to unique parental pairs with one authorized mismatch. Three fish were assigned to more than 1 couple and 2 fish could not be assigned. The rate of assignment to unique pairs was thus $99.75 \%$.

Forty-nine fish assigned to 25 different dams appeared to be triploids based on their genotypic signature showing 3 alleles per markers. These fish exhibited a lower mean weight than diploids (t-test; $\mathrm{p}<0.001 ; 62.2 \pm 17.4 \mathrm{~g}$ for the triploids $v s 73.1 \pm 17.6 \mathrm{~g}$ for the diploids). Their condition coefficient $\mathrm{K}$ was not different $(1.24 \pm 0.13$ for the triploids $v s 1.26 \pm 0.10$ for the diploids, $\mathrm{P}>0.5)$. The genetic analyses were only performed on the 1964 diploid fish assigned to unique pairs. Of the expected 600 full-sib families, $93.1 \%(\mathrm{n}=559)$ were represented in the progeny genotyped. The number of progeny per family ranged from 1 to 13. All 100 sires were represented in the progeny genotyped. The mean number of progeny 
per sire $( \pm \mathrm{SD}$ ) was $21.1 \pm 7.1$, and ranged from 8 to 45 . The 60 dams were all represented, with a mean number of $33.6 \pm 9.6$ progeny per dam, ranging from 12 to 61 .

The representation of the half-sib families was not statistically different between the NORM and the MIN groups, either for sire half-sib families $\left(\chi^{2}=118.3\right.$; 99 d.f.; $\left.p>0.08\right)$ or dam halfsib families $\left(\chi^{2}=74.4 ; 59\right.$ d.f.; $\left.p>0.08\right)$.

\subsection{Heritabilities and non-additive maternal effects.}

Heritabilities and variance components of BW, BL and K in the NORM and the MIN groups, with or without maternal effect in the model, are given in Table 1.

Residual variances increased and additive genetic variances decreased when $\mathrm{m}^{2}$ is included in the models, excepted when maternal variance was close to null. The difference between heritability estimated with models including or not maternal effect was approximately twice the maternal effect variance. For the NORM group, a significant maternal was observed for BW and BL but not for K. The estimated heritability of BW decreased from $0.34 \pm 0.07$ to $0.16 \pm 0.07$ when the maternal effect was included in the model. The same trend was also observed for BL. Heritability of $\mathrm{K}$, for which maternal effect was not significant, was high with or without the inclusion of maternal effect in the model $(0.50 \pm 0.10$ and $0.53 \pm 0.08$ respectively).

In the MIN group, no significant maternal effect was observed on BW, BL or K (see Table 1), with or without the inclusion of sub-group effect in the model. However, a significant subgroup fixed effect (associated with the different sub-groups prior to mixing at $147 \mathrm{dpf}$ ) was observed at $198 \mathrm{dpf}$ on BL, BW and K (p<0.05). When the sub-group effect was added, the maternal effect estimate for BW, BL and $\mathrm{K}$ dropped to $0.00 \pm 00$. Heritability for BW, BL and 
$\mathrm{K}$ estimated without maternal effect but with sub-group effect in the model (Table 1) were moderately high $(0.36 \pm 0.06,0.32 \pm 0.05$ and $0.30 \pm 0.05$, respectively $)$.

Only linear regression between family means of $\mathrm{BW}$ and egg weight was significant $(\mathrm{P}=$ $\left.0.045 ; \mathrm{r}^{2}=0.068\right)$. The significance of covariates potentially describing the maternal origins of maternal effects in the NORM group are given in Table 2. None of these covariates was significant and, in all cases, the magnitude of heritability and maternal effect was unchanged.

\subsection{Estimation of genetic correlations within or between NORM and MIN groups}

Genetic correlations between traits within the NORM and MIN groups are given in Table 3. They were the highest between BW and BL (0.90-0.97), intermediate between BW and K (0.51-0.58) and the lowest between BL and $\mathrm{K}(0.18-0.28)$. Genetic correlations in the MIN group were the highest between $\mathrm{BW}$ and $\mathrm{BL}$ and the lowest for the correlations between $\mathrm{BW}$ or BL and $\mathrm{K}$.

Genetic correlations between the MIN and NORM groups according to three different models are given in Table 4: (1) without or (2) with maternal effect in the model or (3) with maternal effect include in the model (combined model) only when maternal effect was significant (BW and BL in the NORM group). Genetic correlations were high in all cases but were the highest in the combined model: $0.95 \pm 0.07$ for BW, $0.96 \pm 0.07$ for BL and $0.92 \pm 0.07$ for $\mathrm{K}$.

\section{DISCUSSION}

4.1. DNA parentage assignment and spontaneous triploids 
Parentage assignment based on DNA fingerprinting proved to be reliable in this species, as more that $99.8 \%$ of the candidates from the 600 putative families were assigned unambiguously to their 160 potential parents (100 sires and 60 dams). This rate of assignment confirms promising predictions for rainbow trout made by simulations (Estoup et al., 1998), and was higher than those obtained in other experiments with a much more limited number of parents or families: $91 \%$ (10 sires and 10 dams; Herbinger et al., 1995), 91\%-95 \% (2 sires and 48 dams; Fishback et al., 2002), $91 \%$ (20 full-sibs families; 10 sires; Palti et al., 2006), and $89 \%$ (92 full-sib families, 46 sires; Pierce et al., 2008).

Spontaneous triploids were identified based on their DNA signature. Several hypotheses have already been proposed to explain such biological phenomena based on the retention of the second polar body due to incompletely ovulated or over matured spawns and already reported in some salmonids, loaches or Cyprinids (see Piferrer et al., 2009 for review) or in the turbot Haffray et al. (2009). This phenomenon was also found to be associated with too precocious insemination after GnRH therapy to induce ovulation in trout (Sambroni et al., 2008). However, the high number of dams producing spontaneous triploids suggests that this phenomenon is not female specific and broader than suspected until now. The lower body weight of the triploids confirms their lower performance already reported when reared together with diploids (see Piferrer et al., (2008) for review). Estimation of heritability when the limited number of triploids was kept in the dataset did not change heritability (data not shown). This could confirm the limited genetic interaction reported between ploidy levels in rainbow trout or brown trout (Bonnet et al., 1999) but the limited number of triploids in the data set cannot allow estimating this interaction properly. From a breeder's perspective, their lower performances limit their presence among the candidates selected individually on body weight. 


\subsection{Maternal effect}

The protocol and the analysis method used ensures the production of reliable estimates of genetic parameters and maternal effect, as it was based on a partial factorial design and a large number of families and parents (Lynch and Walsh, 1997; Dupont-Nivet et al., 2002; Blanc, 2003; Mrode, 2005). However, our design does not allow concluding about the existence of genetic maternal effects as maternal effect integrates both maternal genetic effects and non genetic maternal effects.

Biases in the estimation of the genetic parameters could have been induced by the different numbers of progeny genotyped between procedures. However, the number of progeny used was at least equal to the minimum proposed by Blanc (2003) in such a mating design.

When the eggs were mixed together at the eyed stage, as in the NORM group, a significant maternal effect was observed for BW and BL at $60 \mathrm{~g}$ mean weight (198 dpf). This observation confirmed previous results obtained with families reared in separate tanks from early stages (Aulstad, 1972; Gall, 1974; Chevassus, 1976; Refstie, 1980, Mc Kay, 1986a; Silverstein et al., 1994; Martínez et al., 1999) or with families mixed at eyed stage in salmonids (Herbinger et al., 1995; Blanc, 2002; Chevassus et al., 2002; Fishback et al., 2002).

In the MIN group, where the difference between female egg weights was limited by subgrouping and early growth management, the maternal effect was not significant. Moreover, the inclusion of a sub-group effect in the statistical model made the maternal effect drop to zero. This showed that the method used for minimizing the maternal effect was efficient. As groups were not replicated, the possibility that this result was obtained by chance cannot be excluded. However, the large number of parents and families used in this experiment and the small standard errors of the heritability obtained indicate that the maternal effect was precisely estimated in both experimental treatments. 
Our results showed the efficiency of the method for minimizing maternal effect, although it is still difficult to fully explain how this method worked. Indeed, since we made sub-groups with similar egg weights in the MIN group, we expected that egg weight would explain a large proportion of the maternal effect. However, when covariates were included in the model, $\mathrm{m}^{2}$ was not modified and none of the covariate was significant, even egg weight the trait that the MIN group was sorted on (see Table 2). Combination of these effects could also be the source of the significant effect. The GnRH stimulation of the ovulation may also have interacted with the expression of the reproductive traits. As the natural ovulation period without hormonal stimulation takes 4 to 5 weeks, the oocytes from the different dams before hormonal induction were supposed to be at different stages of maturation (Haffray et al., 2008). Therefore, difference in egg quality according difference of physiological stage in final maturation process (see discussion part about triploid occurrence) is highly probable but the protocol was not adapted to test this hypothesis. The management of the sub-groups before they were mixed together, and their potential compensatory growth, probably also played a key role, although the nature of such influences is still unknown. Sub-groups were managed in using slightly different feeding ratios on a long duration from first feeding to $147 \mathrm{dpf}$. Other principles using temperature or different densities could also be efficient but were not investigated in this study.

\subsection{Heritabilities and genetic correlations}

The heritabilities of $\mathrm{BW}$ and $\mathrm{BL}$ in the MIN group were moderate and in the same range as those estimated in other experiments done at a similar age in trout (Crandell and Gall, 1993). The difference between heritability in the NORM group with models including or not maternal effect can be explained the following way. As only phenotypes of the offspring 
generation are used, the animal model used in this study fits in a way similar to a sire-dam model. In such a model, variance between dams, VD, is the sum of 1/4 VA (additive genetic variance), VM (maternal variance), plus a fraction of VE (environmental variance), which means that estimates of VA obtained by the dams are 4VD. Thus, the bias brought by the possible presence of $\mathrm{VM}$ is equal to $4 \mathrm{VM}$. Using the mean of the sire (for which there is no such bias by maternal effect) and dam-estimated components of additive variances, the bias should be nearly equal to $2 \mathrm{VM}$, which is close to the difference seen here and also observed by Pante et al. (2002) or Dupont-Nivet et al. (2010).

Heritability of BW and BL were at least twice as high in the MIN group as in the NORM group. Moreover a very high genetic correlation between the two groups has been evidenced. Thus, in case of family selection, selection would result in the choice of same families in both groups and same subsequent genetic progress. In case of individual selection, the picture would be rather different. Indeed, genetic gain is $\mathrm{Dg}=i h^{2} \sigma p$, where $\mathrm{i}$ is the intensity of selection and $\sigma \mathrm{p}$ is the phenotypic standard deviation. Thus, mass selection in the MIN group will lead to higher genetic gain because heritability is higher. This will occur even if there is high genetic correlation between both groups because selection precision is highest in MIN group ie the identification of best individuals will be more accurate.

The heritability of the condition factor $\mathrm{K}$ was much higher in the NORM group than in the MIN group. The heritability estimated in the NORM group was in the range with the heritabilities reported in the literature (see Gjedrem et al., 2005 for a review). The lower value estimated in the MIN group was rarely reported. Several explanations can be advanced. First the condition factor is a ratio between two traits. As pointed by Simms et al., (1987) the trait with the highest coefficient of variation (here body weight) tends to dominate the ratio and its variation can lead to biased estimates, bias enhanced when traits are highly correlated and exhibit high difference in variation coefficient. Secondly, the early phase of management of 
the sub-groups could also have induced growth differential between body compartments (muscle, visceral mass and bones) and modified the fish morphology with more slender morphology in the more restricted fed sub-groups. This hypothesis can be rejected as when the sub-group effect was included in the model, no change in heritability was observed for K. Whatever the cause, the difference in heritability underlined the need to investigate genetic and environmental factors of body morphology.

\section{4- Procedure for minimizing maternal effects}

As performances were only known from only one generation, the genetic maternal effect cannot be estimated. However, the maternal effects were accurately estimated as partly factorial design with each dam mated to several sires were used. The introduction of $\mathrm{m}^{2}$ in the model for the NORM group is needed when eggs from the different families are pooled together at hatching. The effect was close or as good as the managerial intervention entailed in MIN group. However, such correction can only be used in family selection but not in individual selection where pedigrees and thus family breeding values are unknown.

The two combined management practices introduced in the MIN group (sub-grouping and early growth management) cannot be separated in this experiment. Chevassus et al., (2002) observed differences in heritability for growth when sub-families were issued from eggs of the same or different size. This work was not able to demonstrate that the sub-grouping of dams with similar egg weight per se was responsible for the difference of heritability observed due to the small number of dams used $(n=2)$ and the limited number of progeny measured. Both the results of this previous study and the present one underline the potential of such practices to limit maternal effects for experimental or commercial selection purposes in salmonids. 
It is commonly accepted that maternal effects decrease with age and become non significant at commercial size (Mc Kay et al., 1986b; Crandell and Gall, 1993), but in some experiments such effects are still observed at this point (Aulstad, 1972; Gall, 1974; Refstie, 1980; Martínez et al., 1999). In our experiment, fish were only reared until $60 \mathrm{~g}$ and the persistence of maternal effects at a larger size is questionable. A preliminary experiment reported that such effects persisted until more than $400 \mathrm{~g}$ or 17 months old of age (Chevassus et al., 2002). Moreover, these results at $60 \mathrm{~g}$ are also important for individual selection programs since several steps of successive culling are frequently carried out over the growth period to limit the total biomass of reared fish and first culling occurs before $60 \mathrm{~g}$.

\section{CONCLUSIONS}

This study is the first to estimate genetic parameters for growth in salmonid juveniles using a factorial design in which a high number of families are mixed from eyed stage and families are managed to limit potential bias due to maternal effects. It is concluded that maternal effects exist for early growth, at least up to $60 \mathrm{~g}$. An adequate management of the sub-groups differing for dam egg weight between spawns could decrease this maternal bias to zero and substantially increase the heritability for growth and, thus, the efficiency and the accuracy of mass selection. Further experiments are needed to confirm this result and to investigate the persistence of maternal effect in older fish and other Salmonids when eggs are pooled at early stages.

\section{ACKNOWLEDGEMENTS}


We thank Jean Yves Gayral, Jérome Doerflinger, Thierry Espirat and Jean Philippe Angama (Aqualande) for the fish production, Maryse Boulay and Marine Jégaden (SYSAAF) for their assistance with the data collection and preparation, Marine Levadoux (CIPA), Emmanuel Mazeiraud (Aqualande) for their participation in the administrative management of the project and fruitful discussions and Helen Boudry for her support in the English improvement. The study was supported by the French Ministry of Agriculture (Action Innovante $n^{\circ} 2005$ PA01) and the European Union through a collective project (IFOP $\mathrm{n}^{\circ} 2005 / 159$ ) managed by the French interprofessional committee for aquaculture products - Comité Interprofessionnel des Produits de l'Aquaculture (CIPA).

\section{REFERENCES}

Aulstad, D., Gjedrem, T., Skjervold, H., 1972. Genetic and environmental sources of variation in length and weight of rainbow trout (Salmo gairdneri). J. Fish. Res. Board Can., 29, $237-241$.

Berg, O. K., Hendry, A. P., Svendsen, B., Bech, C., Arnekleiv, J. V. \& Lohrmann, A., 2001. Maternal provisioning of offspring and the use of those resources during ontogeny: variation within and between Atlantic Salmon families. Functional Ecology 15, 13-23.

Blanc, J.M., 2002. Effect of egg size difference on juvenile weight between and within lots in rainbow trout Onchorhynchus mykiss. Journal of the World Aquaculture Society, 33(3), 278-286.

Blanc J.M., 2003. Comparison of experimental designs for estimating quantitative genetic parameters in fish. Aquaculture Research, 34, 1099-1105.

Blanc, J.M., Maunas, P., Vallée, F., 2005. Effect of triploidy on paternal and maternal variance components in brown trout, Salmo trutta L. Aquaculture, 36, 1026-1033. 
Bobe, J., Labbé, C., 2010. Egg and sperm quality in fish. Gen Comp Endocrinol., 165(3), 53548.

Bonnet S., Haffray P. , Blanc J.M. , Vallée F., Vauchez C. , Faure A. , Fauconneau B. 1999. Genetic variation in growth parameters until commercial size in diploid and triploid freshwater rainbow trout (Oncorhynchus mykiss) and seawater brown trout (Salmo trutta). Aquaculture, $173: 359-375$.

Chevassus, B., 1976. Variabilité et héritabilité des performances de croissance chez la truite arc-en-ciel (Salmo gairdneri Richardson). Ann. Génét. Sél. Anim., 18, 273-283.

Chevassus, B., 1982. Facteurs génétiques et sociaux influençant la croissance chez les poisons. Oceanis, 8(7), 570-598.

Chevassus B., Dupont-Nivet M., Mauger S., Haffray P., Vandeputte M., 2002. Estimation of heritabilities in two groups of rainbow trout (Oncorhynkus mykiss) with families mixed together since eyed stage. $7^{\text {th }}$ World Congress on Genetics Applied to Livestocks Production. Montpellier, August 19-23, 2002. Book of abstracts, Communication n ${ }^{\circ} 06-$ $09, \mathrm{p} 147$.

Chevassus B, Quillet E, Krieg F, Hollebecq MG, Mambrini M, Labbe L, Hiseux JP, Vandeputte M, 2004. Enhanced individual selection for selecting fast growing fish: the "PROSPER', method, with application on brown trout (Salmo trutta fario). Gen. Sel. Evol. 36, 643-661.

Crandell P.A.,.Gall G.A.E., 1993. The genetics of body weight and its effect on early maturity based on individually tagged rainbow trout (Oncorhynchus mykiss). Aquaculture 117, 77-93.

Dupont-Nivet M., Vandeputte M., and Chevassus B., 2002. Optimisation of factorial mating designs for inference on heritability in fish species. Aquaculture, 204, 361-370. 
Dupont-Nivet M., Vandeputte M., Haffray P., and Chevassus B., 2006. Effect of different mating designs on inbreeding, genetic variance and response to selection when applying individual selection in fish breeding programs. Aquaculture 252: 161-170.

Dupont-Nivet, M., Vandeputte, M., Vergnet, A., Merdy, O., Haffray, P., Chavanne, H., Chatain, B., 2008. Heritabilities and GxE interactions for growth in the European sea bass (Dicentrarchus labrax L.) using a marker-based pedigree. Aquaculture, 275, 81-87.

Dupont-Nivet, M., Chevassus, B., Mauger, S., Haffray, P., Vandeputte, M., 2010. Side effects of sexual maturation on heritability estimates in rainbow trout (Oncorhynchus mykiss). Aquaculture Research, 41, e878-e880.

Estoup A., Gharbi K., SanCristobal M., Chevalet C., Haffray P. and Guyomard R., 1998. Parentage assignment using microsatellites in turbot (Scophtalmus maximus) and rainbow trout (Oncorhynchus mykiss) hatchery populations. Can. J. Fish. Aquat. Sci. 55, $715-725$.

Falconer, D.S., Mackay, T.F.C., 1996. Introduction to Quantitative Genetics. Pearson/Prentice-Hall/Harlow, Essex, UK.

Fishback, A. G., Danzmann, R. G., Ferguson, M. M., Gibson, J. P., 2002. Estimates of genetic parameters and genotype by environment interactions for growth traits of rainbow trout (Oncorhynchus mykiss) as inferred using molecular pedigrees. Aquaculture 206, 137150.

Gall, G.A.E., 1974. Influence of size of egg and age of female on hatchability and growth in rainbow trout. Calif. Fish Game, 60, 26-36.

Gjedrem, T., Thodesen, J., 2005. Selection. In: Gjedrem, T. (Ed.), Selection and Breeding Programs in Aquaculture. Springer, Dordrecht, The Netherlands, pp. 89-111.

Green, B., S., 2008. Maternal Effects in Fish Populations. Advances in Marine Biology, Volume 54. 
Guy, D., R., Bishop, S., C., Brotherstone, S., Hamilton, A., Roberts, R., J., McAndrew, B., Woolliams, J. A., 2006. Analysis of the incidence of infectious pancreatic necrosis mortality in pedigreed Atlantic salmon, Salmo salar L., populations. Journal of Fish Diseases, 29, 637-647.

Haffray P., Pincent C., Rault P., Coudurier B., 2004. Domestication et amélioration génétique des cheptels piscicoles français dans le cadre du SYSAAF. INRA Prod. Anim. 17(3): $243-252$.

Haffray P., Sambroni E., Enright W.J., Driancourt M.A., Mikolajczyk T., Rault, P., Breton B.' 2008. Efficiency of Gonazon ${ }^{\mathrm{TM}}$ in rainbow trout, the first officially approved inducer of ovulation in the EU. Cybium, 32(2), 312-313.

Haffray, P., Lebègue, E., Jeu, S., Guennoc, M., Guiguen, Y., Baroiller, J.F., Fostier, A., 2009. Genetic and temperature sex determination using sex reversed breeders in the turbot Scophthalmus maximus. Aquaculture, 294, 30-36.

Herbinger, C.M., Doyle, R.W., Pitman, E.R., Paquet, D., Mesa, K.A., Morris, D.B., Wright, J.M., Cook, D., 1995. DNA fingerprint based analysis of paternal and maternal effects on offspring growth and survival in communally reared rainbow trout. Aquaculture 137, $245-256$.

Herbinger C.M., O'Reilly P.T., Doyle R.W., Wright J.M., O'Flynn F., 1999. Early growth performance of Atlantic salmon full-sib families reared in single family tanks versus in mixed family tanks. Aquaculture 173, 105-116.

Kovac, M., Groeneveld, E., 2003. VCE-5 User's Guide and Reference Manual Version 5.1, Institute of Animal Science, Federal Agricultural Research Center, Mariensee, Germany. 68 pp.

Lynch, M., Walsh, B., 1997. Genetics and quantitative analysis of quantitative traits. Ed., Sinauer Associates. 980 p. 
Martínez, V., Neira, R., Gall, G.A.E., 1999. Estimation of genetic parameters from pedigree populations: lessons from analysis of alevin weigh in coho salmon (Oncorhynchus kisutch). Aquaculture, 180, 223-236.

McKay, L.R., Ihssen, P.E., Friars, G.W., 1986a. Genetic parameters of growth in rainbow trout, Salmo gairdneri, prior to maturation. Can. J. Genet. Cytol., 28, 306-312.

McKay, L.R., Ihssen, P.E., Friars, G.W., 1986b. Genetic parameters of growth in rainbow trout, Salmo gairdneri, as a function of age and maturity. Aquaculture, 58, 241-254.

Mrode, R.A., 2005. Linear models for the prediction of animal breeding values, $2^{\text {nd }}$ Edition. Cabi Publishing, 344 p.

Nilsson, J., 1994. Genetics of growth of juvenile Arctic char. Trans. Am. Fish. Soc. 123, 430434.

Ninh, N.H., Ponzoni, R.W., Nguyen, N. H., Woolliams, J.A., Taggart, J.B., McAndrew, B.J., Pennman, D.J., 2011. A comparison of communal and separate rearing of families in selective breeding of common carp (Cyprinus carpio): estimation of genetic parameters. Aquaculture, 322-323, 39-46.

Norris, A. T., Cunningham, E. P., 2004. Estimates of phenotypic and genetic parameters for flesh colour traits in farmed Atlantic salmon based on multiple trait animal model. Livestock Production Science 89, 209-222.

Palti, Y., Silverstein, J.T., Wieman, H., Phillips, J.G., Barrows, F.T., Parsons, J.E., 2006. Evaluation of family growth response to fishmeal and gluten-based diets in rainbow trout (Oncorhynchus mykiss). Aquaculture 255, 548-556.

Pante, M.J.R., Gjerde, B., McMillan, I., Misztal, I., 2002. Estimation of additive and dominance genetic variances for body weight at harvest in rainbow trout, Oncorhynchus mykiss. Aquaculture 204, 383-392.

Pierce, L.R., Palti, Y., Silverstein, J.T., Barrows, F.T., Hallerman, E.M., Parsons, J.E., 2008 
Family growth response to fishmeal and plant-based diets shows genotype 3 diet interaction in rainbow trout (Oncorhynchus mykiss). Aquaculture 278: 37-42.

Piferrer, F., Beaumont, A., Falguière, J.C., Colombo, L, Flajshans, M., Haffray, P., 2009. The use of induced polyploidy in the aquaculture of fish and shellfish for performance improvement and genetic containment. Aquaculture, 293, 125-156.

Refstie, T., 1980. Genetic and environmental sources of variation in body weight and length of rainbow trout fingerling. Aquaculture, 19, 351-357.

Sambroni, E., Kerneis, T., Labbé, L., Jalabert, B., 2008. Precocious insemination after induced ovulation increases the occurrence of triploid offspring in rainbow trout Oncorhynchus mykiss. Cybium, 32(2), 261.

Silverstein, J.T., Hershberger, W.K., 1994. Genetic parameters of size pre- and postsmoltification in coho salmon (Oncorhynchus kisutch). Aquaculture, 67-77.

Simms, G., Smith, C., Thompson, R., 1987. The use of product traits such as lean growth rate as selection criteria in animal breeding. Animal Production, 45, 307-316.

Vandeputte M. Quillet E. and Chevassus B., 2002. Early development and survival in brown trout (Salmo trutta fario L.): indirect effects of selection for growth rate and estimation of genetic parameters. Aquaculture, 204, 435-445.

Vieira V.L.A., Norris A. and Johnston I.A., 2008. Heritability of fibre number and size parameters and their genetic relationship to flesh quality traits in Atlantic salmon (Salmo salar L.). Aquaculture 272, 100-109. 
Table 1. Variance components, heritability $\left(\mathrm{h}^{2} \pm\right.$ standard error) and maternal effect ( $\mathrm{m}^{2} \pm$ standard error) of body weight (BW), body length (BL) and condition factor $(\mathrm{K})$ in rainbow trout estimated in the NORM and the MIN groups with maternal effect included or not in the model. NORM = maximum expected maternal effect, MIN = minimal expected maternal effect, MIN2 = minimum expected maternal effect with sub-group effect included in the model as fixed effect.

\begin{tabular}{|c|c|c|c|c|c|c|c|c|c|}
\hline Trait & Group & Model & Animal variance & Maternal variance & Residual variance & Heritability & $\mathrm{m}^{2}$ & LL & Significance \\
\hline \multirow[b]{6}{*}{ BW } & \multirow[b]{2}{*}{ NORM } & without $\mathrm{m}^{2}$ & 105.92 & (2) & 206.914 & $0.34 \pm 0.07$ & - & 1846.8 & \multirow[t]{2}{*}{$*$} \\
\hline & & with $\mathrm{m}^{2}$ & 50.189 & 26.388 & 234.903 & $0.16 \pm 0.07$ & $0.08 \pm 0.03$ & 1839.3 & \\
\hline & \multirow[b]{2}{*}{ MIN } & without $\mathrm{m}^{2}$ & 133.574 & - & 185.861 & $0.42 \pm 0.06$ & - & 3332.9 & \multirow[t]{2}{*}{ NS } \\
\hline & & with $\mathrm{m}^{2}$ & 111.809 & 10.029 & 196.915 & $0.35 \pm 0.07$ & $0.03 \pm 0.03$ & 3331.6 & \\
\hline & \multirow[b]{2}{*}{ MIN2 } & without $\mathrm{m}^{2}$ & 110.225 & - & 195.352 & $0.36 \pm 0.06$ & - & 3342.5 & \multirow[t]{2}{*}{ NS } \\
\hline & & with $\mathrm{m}^{2}$ & 110.22501 & 0.003 & 208.768 & $0.36 \pm 0.06$ & $0.00 \pm 0.00$ & 3342.5 & \\
\hline \multirow[b]{6}{*}{$\mathrm{BL}$} & \multirow[b]{2}{*}{ NORM } & without $\mathrm{m}^{2}$ & 0.5855 & - & 1.383 & $0.31 \pm 0.07$ & - & 1848.1 & \multirow[t]{2}{*}{$*$} \\
\hline & & with $\mathrm{m}^{2}$ & 0.2827 & 0.1443 & 1.5345 & $0.15 \pm 0.07$ & $0.08 \pm 0.03$ & 1841.2 & \\
\hline & \multirow[b]{2}{*}{ MIN } & without $\mathrm{m}^{2}$ & 0.754 & - & 1.304 & $0.37 \pm 0.06$ & - & 3366.6 & \multirow[t]{2}{*}{ NS } \\
\hline & & with $\mathrm{m}^{2}$ & 0.6441 & 0.0507 & 1.3594 & $0.31 \pm 0.07$ & $0.02 \pm 0.05$ & 3365.6 & \\
\hline & \multirow[b]{2}{*}{ MIN2 } & without $\mathrm{m}^{2}$ & 0.61 & - & 1.32 & $0.31 \pm 0.05$ & - & 3378.6 & \multirow[t]{2}{*}{ NS } \\
\hline & & with $\mathrm{m}^{2}$ & 0.61 & $<0.0001$ & 1.32 & $0.31 \pm 0.05$ & $0.00 \pm 0.00$ & 3378.6 & \\
\hline \multirow[b]{6}{*}{ K } & \multirow[b]{2}{*}{ NORM } & without $\mathrm{m}^{2}$ & 0.0055 & - & 0.0047 & $0.53 \pm 0.08$ & - & 1784.6 & \multirow[t]{2}{*}{ NS } \\
\hline & & with $\mathrm{m}^{2}$ & 0.0051 & 0.0002 & 0.0051 & $0.50 \pm 0.10$ & $0.02 \pm 0.04$ & 1784.4 & \\
\hline & \multirow[b]{2}{*}{ MIN } & without $\mathrm{m}^{2}$ & 0.0022 & - & 0.0051 & $0.30 \pm 0.05$ & - & 3407.3 & \multirow[t]{2}{*}{ NS } \\
\hline & & with $\mathrm{m}^{2}$ & 0.0019 & $<0.0001$ & 0.0052 & $0.27 \pm 0.06$ & $0.02 \pm 0.02$ & 3407.3 & \\
\hline & \multirow[b]{2}{*}{ MIN2 } & without $\mathrm{m}^{2}$ & 0.003 & - & 0.007 & $0.30 \pm 0.05$ & - & 3334.7 & \multirow[t]{2}{*}{ NS } \\
\hline & & with $\mathrm{m}^{2}$ & 0.0029 & 0.0001 & 0.0071 & $0.29 \pm 0.07$ & $0.00 \pm 0.00$ & 3434.5 & \\
\hline
\end{tabular}


Table 2: Heritability $\left(\mathrm{h}^{2} \pm\right.$ standard error) and matenal effects $\left(\mathrm{m}^{2} \pm\right.$ standard error $)$ in the NORM group for body weight (BW), body length (BL) and coefficient of condition (K) with or without different reproductive traits included in the model as a covariate.

\begin{tabular}{|c|c|c|c|c|c|c|}
\hline Trait & covariate & $\begin{array}{l}\mathrm{h}^{2} \text { without } \\
\text { covariate }\end{array}$ & $\begin{array}{l}\mathrm{h}^{2} \text { with } \\
\text { covariate }\end{array}$ & $\begin{array}{l}\mathrm{m}^{2} \text { without } \\
\text { covariate }\end{array}$ & $\begin{array}{l}\mathrm{m}^{2} \text { with } \\
\text { covariate }\end{array}$ & $\begin{array}{c}\text { significance } \\
\text { of the } \\
\text { covariate }^{1}\end{array}$ \\
\hline \multirow{5}{*}{ BW } & Egg weight & \multirow{5}{*}{$0.16 \pm 0.07$} & $0.17 \pm 0.07$ & \multirow{5}{*}{$0.08 \pm 0.03$} & $0.08 \pm 0.03$ & $\mathrm{NS}$ \\
\hline & Dam weight & & $0.16 \pm 0.07$ & & $0.09 \pm 0.04$ & NS \\
\hline & Egg number & & $0.16 \pm 0.07$ & & $0.08 \pm 0.03$ & NS \\
\hline & Relative fecundity & & $0.16 \pm 0.07$ & & $0.08 \pm 0.04$ & $\mathrm{NS}$ \\
\hline & $\begin{array}{l}\text { Survival at eyed } \\
\text { stage }\end{array}$ & & $0.16 \pm 0.07$ & & $0.09 \pm 0.04$ & NS \\
\hline \multirow{5}{*}{$\mathrm{BL}$} & Egg weight & \multirow{5}{*}{$0.15 \pm 0.07$} & $0.15 \pm 0.07$ & \multirow{5}{*}{$0,08 \pm 0,03$} & $0.06 \pm 0.03$ & NS \\
\hline & Dam weight & & $0.14 \pm 0.07$ & & $0.08 \pm 0.03$ & $\mathrm{NS}$ \\
\hline & Egg number & & $0.15 \pm 0.07$ & & $0.07 \pm 0.03$ & NS \\
\hline & Relative fecundity & & $0.15 \pm 0.07$ & & $0.07 \pm 0.03$ & $\mathrm{NS}$ \\
\hline & $\begin{array}{l}\text { Survival rate at } \\
\text { eyed stage }\end{array}$ & & $0.14 \pm 0.07$ & & $0.08 \pm 0.03$ & NS \\
\hline \multirow[t]{5}{*}{ K } & Egg weight & \multirow{5}{*}{$0.50 \pm 0.10$} & $0.49 \pm 0.11$ & \multirow{5}{*}{$0.02 \pm 0.04$} & $0.02 \pm 0.04$ & NS \\
\hline & Dam weight & & $0.49 \pm 0.11$ & & $0.02 \pm 0.04$ & $\mathrm{NS}$ \\
\hline & Egg number & & $0.50 \pm 0.11$ & & $0.02 \pm 0.04$ & $\mathrm{NS}$ \\
\hline & Relative fecundity & & $0.50 \pm 0.11$ & & $0.02 \pm 0.04$ & $\mathrm{NS}$ \\
\hline & $\begin{array}{l}\text { Survival rate at } \\
\text { eyed stage }\end{array}$ & & $0.49 \pm 0.11$ & & $0.02 \pm 0.04$ & $\mathrm{NS}$ \\
\hline
\end{tabular}

1- *: covariate significant $(\mathrm{P}<0.05)$; NS : covariate non significant $(\mathrm{P}>0.05)$. 
Table 3: Genetic correlations ( \pm standard error) between the traits body weight $(\mathrm{BW})$, body length (BL) and the condition factor (K) within the two groups NORM and MIN at 198 days post-fertilisation (dpf).

\begin{tabular}{|l|c|c|}
\hline & $\begin{array}{c}\text { Within NORM } \\
\text { group }\end{array}$ & $\begin{array}{c}\text { Within MIN } \\
\text { group }\end{array}$ \\
\hline BW-BL & $0.90 \pm 0.07$ & $0.97 \pm 0.01$ \\
\hline BW-K & $0.58 \pm 0.14$ & $0.51 \pm 0.09$ \\
\hline BL-K & $0.18 \pm 0.10$ & $0.28 \pm 0.11$ \\
\hline
\end{tabular}

Table 4: Genetic correlations ( \pm standard error) between the same traits measured in groups NORM and MIN, for the traits body weight (BW), body length (BL) and the condition factor (K) at 198 days post fertilisation (dpf) without or with maternal effect included in the model for both traits or with maternal effect included in the model only for the traits for which it was significant (BW and BL in the NORM group).

\begin{tabular}{|l|c|c|c|}
\hline & $\begin{array}{c}\text { Without maternal } \\
\text { effect }\end{array}$ & $\begin{array}{c}\text { With maternal } \\
\text { effect }\end{array}$ & $\begin{array}{c}\text { Combined } \\
\text { model }\end{array}$ \\
\hline BW 'NORM' - BW 'MIN' & $0.89 \pm 0.07$ & $0.92 \pm 0.07$ & $0.95 \pm 007$ \\
\hline BL'NORM' - BL'MIN' & $0.91 \pm 0.07$ & $0.92 \pm 0.11$ & $0.96 \pm 0.07$ \\
\hline K 'NORM' - K 'MIN' & $0.92 \pm 0.07$ & $0.92 \pm 0.11$ & $0.92 \pm 0.07$ \\
\hline
\end{tabular}




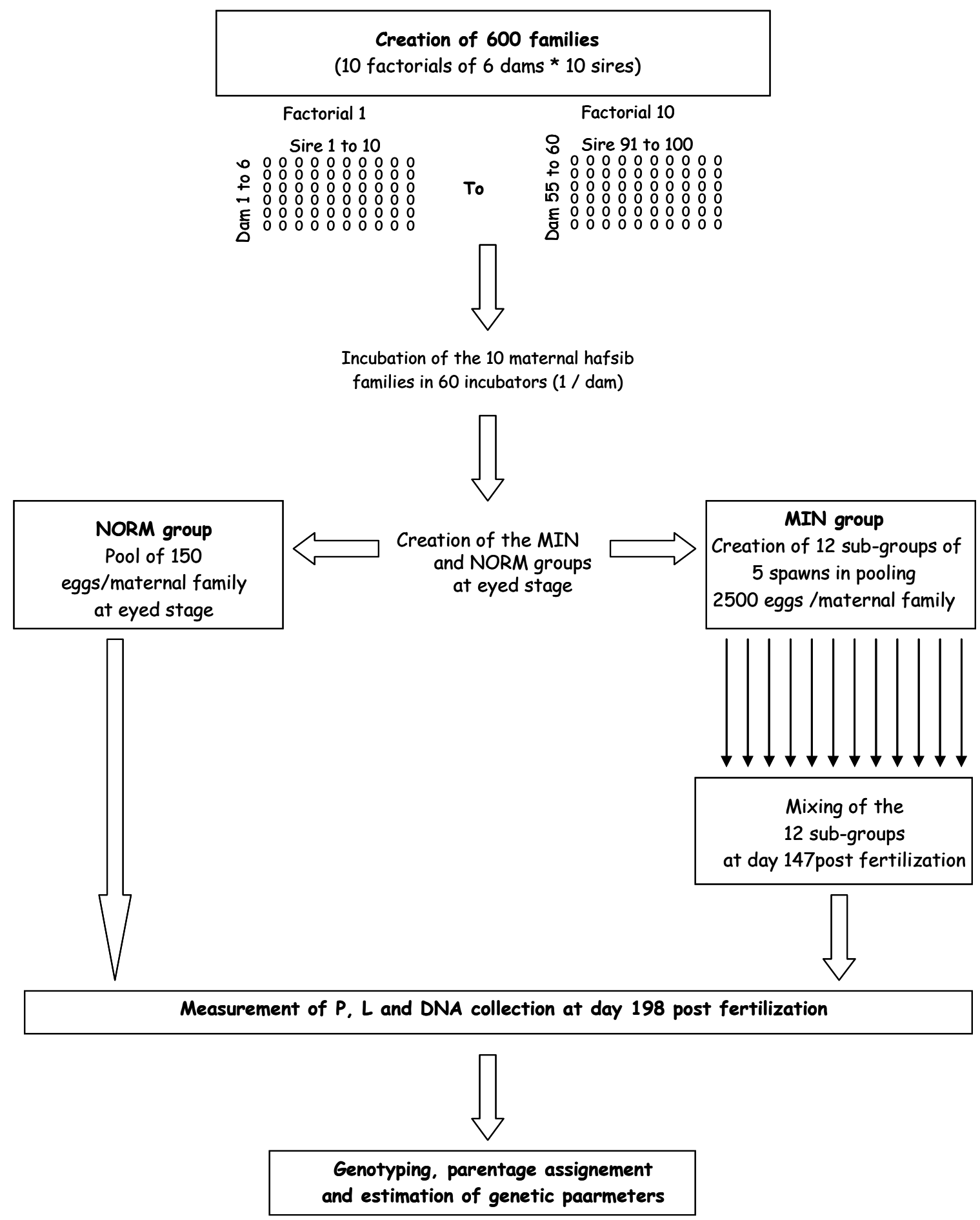

Figure 1: Schematic representation of the experiment from the creation of the families to the estimation of genetic parameters at 198 days post fertilization, including the creation of the NORM and the MIN groups (see adding information in paragraph 2.2). 